\title{
Assessment of combined toxic effects of potassium bromate and sodium nitrite in some key renal markers in male Wistar rats
}

\author{
*Adewale O.O., Aremu K.H., Adeyemo A.T.
}

\begin{abstract}
Objective: Potential combined nephrotoxic effect following simultaneous administration of two food additives: potassium bromate (PBR) $(20 \mathrm{mg} / \mathrm{kg}$ of body weight, twice weekly) and sodium nitrite (SNT) $(60 \mathrm{mg} / \mathrm{kg}$ of body weight as a single dose) orally was investigated.
\end{abstract}

Methods: Nephrotoxicity was assessed by determining urea, creatinine and electrolyte concentrations in the serum. In addition, concentrations of nitric oxide, reduced glutathione, total thiol, malondialdehyde and activities of arginase, adenosine deaminase, catalase, superoxide dismutase, and glutathione perioxidase in the kidney were investigated.

Results: The results revealed that individual exposure to PBR or SNT significantly induced nephrotoxicity and oxidative stress in rats however, this was enhanced by co-exposure as evidenced by significant alteration in these kidney markers when compared with the control.

Conclusion: This study accentuates the risk of enhanced nephrotoxicity in food containing both additives.

Key words: Potassium bromate, sodium nitrite, renal markers.

*Corresponding Author

Adewale 0.O.

http://orcid.org/0000-0003-0387-585X

Department of Biochemistry, Faculty of Basic and Applied Sciences, Osun State University, Osogbo, Nigeria 


\title{
Évaluation des effets toxiques combinés du brome de potassium et du nitrite de sodium dans certains marqueurs rénaux clés chez les rats mâles Wistar
}

\author{
*Adewale O.O., Aremu K.H., Adeyemo A.T.
}

\section{Résumé}

Objectif: Un effet néphrotoxique combiné potentiel après l'administration simultanée de deux additifs alimentaires: bromate de potassium (PBR) $(20 \mathrm{mg} / \mathrm{kg}$ de poids corporel, deux fois par semaine) et nitrite de sodium (SNT) $(60 \mathrm{mg} / \mathrm{kg}$ de poids corporel en une seule dose) par voie orale a été étudié. .

Méthode de l'étude: La néphrotoxicité a été évaluée en déterminant les concentrations d'urée, de créatinine et d'électrolytes dans le sérum. De plus, les concentrations d'oxyde nitrique, de glutathion réduit, de thiol total, de malondialdéhyde et les activités de l'arginase, de l'adénosine désaminase, de la catalase, de la su peroxyde dismutase et de la glutathion peroxydasse dans le rein ont été étudiées.

Résultats: Les résultats ont révélé que l'exposition individuelle au PBRor SNT induisait cependant de manière significative la néphrotoxicité et le stress oxydatif chez le rat ; cela a été amélioré par la Coexposition comme en témoigne une altération significative de ces marqueurs rénaux par rapport au témoin.

Conclusion: Cette étude accentue le risque de néphrotoxicité accrue dans les aliments contenant les deux additifs.

Mots clés: Bromate de potassium, nitrite de sodium, marqueurs rénaux

\footnotetext{
*Auteur Correspondant

Adewale 0.O.

http://orcid.org/0000-0003-0387-585X
}

Department of Biochemistry, Faculty of Basic and Applied Sciences, Osun State University, Osogbo, Nigeria 


\section{INTRODUCTION}

Food additives are substances added to food to preserve flavour or enhance its taste and appearance (1). In the past, meats, fish and fruits were preserved with natural products like salt and sugar, but nowadays, with the advent of processed food, many more additives and preservatives have been introduced. Among many commonly used food additives are potassium bromate $\left(\mathrm{KBrO}_{3}\right)$ and sodium nitrite $\left(\mathrm{NaNO}_{2}\right)$. Individually, each of these substances serve important roles as a food additive in food processing industries, as well as important agent in some other industries including cosmetics, textile and even in health sector (2). For example, potassium bromate is a strong oxidizing agent that has been extensively used as an additive in food and cosmetics industries, while the use of sodium nitrite $\left(\mathrm{NaNO}_{2}\right)$ as preservative and curative agents in food and drug industries have been widely reported $(3,4)$.

Exposure to additives may be through direct or indirect (intentional and unintentional) applications, to maximize profit, improve quality and to increase aesthetic value as well as to preserve excess (1). Despite their important roles, some of these substances including $\mathrm{NaNO}_{2}$ and $\mathrm{KBrO}_{3}$ induce hepatotoxicity, nephrotoxicity, neurotoxicity, thyroid toxicity; and cause the development of mesothelioma tumors in experimental animals as well as renal carcinomas in animals and humans $(2,4)$. Individually, induced toxicity and carcinogenicity of $\mathrm{NaNO}_{2}$ and $\mathrm{KBrO}_{3}$ in various tissues especially of rodents have been reported (3). For instance, $\mathrm{KBrO}_{3}$ is a major tap water pollutant (2) and results of mechanistic studies have proposed that exposure to bromate causes renal toxicity in man and experimental animals through lipid peroxidation and DNA damage $(4,5)$. Reports of other studies have also indicated the ability of $\mathrm{KBrO}_{3}$ to induce kidney injury and even carcinogenicity in different experimental models $(3,4)$. Chronic exposure to lower doses of $\mathrm{NaNO}_{2}$ has also been reported to cause adverse health effects, which includes birth defects, respiratory tract ailments, damage to the nervous system and paralysis (6) as well as carcinogenicity and mutagenicity (3). Apart from common exposure to small concentration of nitrite through food, water and other sources, exposures to high doses of nitrite intentionally or accidentally have also been documented (6). High concentration of $\mathrm{NaNO}_{2}$ have been employed in other to extend the shelf life span and maintain cured color of meat, or to efficiently control microorganisms like Clostridium botulinum, thus, predisposing humans to its toxic effects (7). Consumption of such foods preserved with high concentration of $\mathrm{NaNO}_{2}$ and with even low concentration of $\mathrm{KBrO}_{3}$ by humans is very likely to predispose them to severe health risks.

Among the important organs in the body, kidney plays a critical role ranging from detoxification to maintenance of fluid balance. With respect to its physiological role, the kidney can be considered as one of the major target organs of exogenous toxicants. $\mathrm{KBrO}_{3}$ has been in this regard confirmed to labialize cell membranes of the kidney of rats and can also results in renal failure, neuropathological disorders and thrombocytopenia in humans $(4,8)$. The nephrotoxicity caused by $\mathrm{KBrO}_{3}$ has been attributed to its ability to trigger the production of reactive oxygen species (ROS), lipid peroxidation and 8-hydroxyguanosine modification in renal DNA (5). Also, $\mathrm{NaNO}_{2}$ taken through contaminated drinking water or food, primarily affects the kidney and cause changes in the activities of some key renal markers (9).

It is clearly known that individual exposure to $\mathrm{KBrO}_{3}$ and $\mathrm{NaNO}_{2}$ poses great ill effects to both humans and rodents especially to the kidney. Likewise, it has been reported that a relatively large number of humans are exposed to both $\mathrm{KBrO}_{3}$ and $\mathrm{NaNO}_{2}$ implying that a greater threat might be posed to the kidney $(1,2)$. Experimental studies have reported several toxicities induced by exposure to the individual food additives $(4,10,11)$. However, reports on the nephrotoxic effect of the combination of $\mathrm{KBrO}_{3}$ and $\mathrm{NaNO}_{2}$ are scarce in literature. In the light of this, the present work was undertaken to analyse the effects of co-exposure to $\mathrm{KBrO}_{3}$ and $\mathrm{NaNO}_{2}$ on some key renal markers in male Wistar rats.

\section{MATERIALS AND METHODS Chemicals}

Potassium bromate $\left(\mathrm{KBrO}_{3}\right)$ and Sodium nitrite $\left(\mathrm{NaNO}_{2}\right)$ were supplied by Labtech Chemicals Nig. Ltd, Lagos, Nigeria. Glutathione (GSH), 5, 5-dithio bis-2-nitrobenzene (DTNB), 2-thiobarbituric acid (TBA) and hydrogen peroxide $\left(\mathrm{H}_{2} \mathrm{O}_{2}\right)$ were purchased from Sigma Chemical Co. (St. Louis, MO, USA). Sodium hydroxide $(\mathrm{NaOH})$, copper (II) sulfate pentahydrate $\left(\mathrm{CuSO}_{4} \cdot 5 \mathrm{H}_{2} \mathrm{O}\right)$ and potassium iodide (KI) were from the British Drug Houses (Poole, Dorset, UK). 


\section{Animal protocol}

Twenty (20) apparently healthy male wistar rats (Rattus norvegicus) with average weight of 120-150 g were provided with food and water ad libitum. The rats were randomly distributed into four groups of five (5) rats each. Experimental procedures involving animals were conducted in accordance the European Convention for the Protection of Vertebrate Animals used for Experimental and other Scientific Purposes guidelines -ETS-123 (2005). The study protocol was approved by ethical committee of College of Health Sciences Osun State University, Osogbo, the rats were acclimatized to laboratory condition for two weeks. Treatment was done orally. The following experimental groups ( $\mathrm{n}=5$ rats per group) were studied:

Group 1: (control); animals were untreated

Group 2: animals were treated with $20 \mathrm{mg} / \mathrm{kg}$ bw of $\mathrm{KBrO}_{3}$ twice a week for four weeks

Group 3: animals were treated with a single acute dose of $\mathrm{NaNO}_{2}$ at $60 \mathrm{mg} / \mathrm{kg}$ bw. Acute dose $(60$ $\mathrm{mg} / \mathrm{kg}$ bw) of $\mathrm{NaNO}_{2}$ was administered $24 \mathrm{hrs}$ before sacrifice.

Group 4: animals were treated with $20 \mathrm{mg} / \mathrm{kg}$ bw and $60 \mathrm{mg} / \mathrm{kg}$ bw of $\mathrm{KBrO}_{3}$ and $\mathrm{NaNO}_{2}$ respectively

Rats in all groups were provided free access to drinking water throughout the twenty-eight (28) days of study. After the completion of dosages, rats were kept for $24 \mathrm{hrs}$, anaesthetized and sacrificed by cervical dislocation.

\section{Serum preparation}

At the end of the treatment period, all rats were fasted overnight, and anaesthetized using light ether. Blood was collected through hepatic portal vein into clean plain and dry sample bottles. The blood was allowed to clot for $10 \mathrm{~min}$ at room temperature and thereafter centrifuged at $3000 \mathrm{rpm}$ for $15 \mathrm{~min}$. Sera were collected by aspiration into clean, dry sample bottles and kept frozen. The sera were used for the kidney function test within 12 hours of preparation.

\section{Preparation of kidney homogenates}

Kidney tissues were excised and rinsed in ice cold $1.15 \% \mathrm{KCl}$, blotted dry and weighed. The tissues were homogenized and centrifuged at $10,000 \mathrm{x} \mathrm{g}$ for $15 \mathrm{mins}$ at $4^{\circ} \mathrm{C}$ and supernatant was used for subsequent assays.

\section{Determination of biochemical parameters (i) Determination of renal function biomarkers}

The concentrations of serum cation and anion electrolytes $\left(\mathrm{Na}^{+}, \mathrm{K}^{+}, \mathrm{Cl}^{-}\right.$, and $\left.\mathrm{HCO}_{3}{ }^{-}\right)$were determined by an automated selective-ion electrolyte analyzer while concentrations of serum urea and creatinine were determined using a kit from Randox Laboratories Ltd, UK.

(ii) Estimation of kidney nitric oxide concentration

The estimation of nitric oxide (NO) level in the kidney homogenates was determined using a solution containing $2 \%$ vanadium chloride $\left(\mathrm{VCl}_{3}\right)$ in $5 \% \mathrm{HCl}(400 \mathrm{~mL}), 0.1 \% \mathrm{~N}$-(1-naphthyl) ethylenediaminedihydrochloride $(200 \mathrm{~mL}), 2 \%$ sulfanilamide (in 5\% HCl) $(200 \mathrm{~mL})$. Incubation at $37^{\circ} \mathrm{C}$ was carried out for 60 mins. Using spectrophotometer at $540 \mathrm{~nm}$, nitrite levels which correspond to NO levels were determined (12). Nitrite and nitrate levels were expressed as nmol of $\mathrm{NO} / \mathrm{mg}$ of protein.

\section{(iii) Evaluation of Arginase assay}

The arginase activity was determined by the method of Romero (13). The reaction solution contained: $50 \mu \mathrm{L}$ tissue homogenate, $75 \mu \mathrm{L}$ Tris $-\mathrm{HCl}(50 \mathrm{mmol} / \mathrm{L}, \mathrm{pH} 7.5)$ and $10 \mathrm{mmol} / \mathrm{L}$ $\mathrm{MnCl}_{2}$. The solution was heated at $55-60^{\circ} \mathrm{C}$ to activate arginase for 10 mins. The activated arginase was incubated with $50 \mu \mathrm{L}$ of L-arginine $(0.5 \mathrm{~mol} / \mathrm{L}, \mathrm{pH} 9.7)$ at $37^{\circ} \mathrm{C}$ for $1 \mathrm{hr}$ and the hydrolysis was stopped using $400 \mu \mathrm{L}$ acid solution mixture of ratio 1:3:7 $\left(\mathrm{H}_{2} \mathrm{SO}_{4}: \mathrm{H}_{3} \mathrm{PO}_{4}: \mathrm{H}_{2} \mathrm{O}\right)$. For calorimetric determination of urea, isonitrosopropiophenone ( $25 \mu \mathrm{L}, 9 \%$ in absolute ethanol) was added to the mixture, heated at $100^{\circ} \mathrm{C}$ for 45 mins. and kept in dark for 10 mins. Urea concentration was determined spectrophotometrically at $550 \mathrm{~nm}$ with the aid of a microplate reader. After normalization with protein, the level of urea produced was used as an index for arginase activity.

(iv) Determination of Adenosine deaminase assay (ADA)

Adenosine deaminase (ADA) activity was determined by the method of Giusti and Galanti (14). This method is based on the measurement of ammonia which is produced when ADA reacts with adenosine in excess. $50 \boldsymbol{\mu L}$ of kidney homogenate was added to $21 \mathrm{mmol} / \mathrm{L}$ of adenosine $(\mathrm{pH} 6.5)$ and incubated at $37^{\circ} \mathrm{C}$ for 60 min. Results were expressed in U/L. One unit $(1 \mathrm{U})$ of ADA was defined as the amount of enzyme required to release $1 \mathrm{mmol}$ of ammonia 
per minute from adenosine.

\section{(v) Estimation of Catalase assay}

Catalase activity was estimated in tissue homogenate using Aebi's method (15). A cuvette containing $50 \mu \mathrm{L}$ lysate, $450 \mu \mathrm{L}$ of phosphate buffer (0.1M, pH 7.4) and $500 \mu \mathrm{L}$ of $20 \mathrm{mM} \mathrm{H}_{2} \mathrm{O}_{2}$ was measured for catalase activity using spectrophotometer at $240 \mathrm{~nm}$ for $1 \mathrm{~min}$. One unit of activity equals $1 \mathrm{mmol}$ of $\mathrm{H}_{2} \mathrm{O}_{2}$ degraded per minute and is expressed as units $/ \mathrm{mg}$ protein.

(vi) Evaluation of Superoxide Dismutase (SOD) assay

Superoxide dismutase activity was estimated by the method of McCord and Fridovich (16). Using spectrophotometer, the absorbance $(420 \mathrm{~nm}$ for 3 min) of a solution containing $2.5 \mathrm{ml}$ of $75 \mathrm{mM}$ of Tris- $\mathrm{HCl}$ buffer (pH 8.2), $30 \mathrm{mM}$ EDTA, $300 \mu \mathrm{L}$ of $2 \mathrm{mM}$ of pyrogallol and $200 \mu \mathrm{L}$ of the homogenate was recorded. One unit of enzyme activity is $50 \%$ inhibition of the rate of autooxidation of pyrogallol as determined by change in absorbance $/ \mathrm{min}$ at $420 \mathrm{~nm}$. The activity of $\mathrm{SOD}$ is expressed as units/mg protein.

(vii) Determination Glutathione Peroxidase (GPx) assay

Glutathione peroxidase (GPx) activity was determined by the method described by Rotruck (17). The assay mixture contains $0.25 \mathrm{~mL}$ sodium phosphate buffer $(0.2 \mathrm{M}, \mathrm{pH} 8.0), 0.05 \mathrm{~mL} 10$ mM sodium azide, $0.1 \mathrm{~mL} 4 \mathrm{mM}$ GSH, $0.05 \mathrm{~mL}$ $2.5 \mathrm{mM} \mathrm{H}_{2} \mathrm{O}_{2}$ and $50 \mu 1$ of homogenate sample in a total volume of $1 \mathrm{~mL}$ with distilled water. The solution was incubated at $37^{\circ} \mathrm{C}$ for 3 mins and terminated with $0.25 \mathrm{~mL}$ of $10 \%$ TCA. The mixture was centrifuged ( $3000 \mathrm{rpm}$ for $10 \mathrm{mins}$ ) and $2.0 \mathrm{~mL}$ of $\mathrm{Na}_{2} \mathrm{HPO}_{4}(0.3 \mathrm{M})$ solution and 0.5 $\mathrm{mL}$ DTNB were added to the supernatant. Change in colour intensity was measured using spectrophotometer at $412 \mathrm{~nm}$ and activity expressed as Units/mg.

(viii) Estimation of reduced Glutathione (GSH)

Reduced glutathione (GSH) concentration was measured by the method described by Jollow (18). Briefly, kidney homogenates were deproteinized by adding $0.15 \mathrm{M}$ sulphosalicyclic acid $(1: 1, \mathrm{v} / \mathrm{v})$. The protein precipitate was centrifuged ( $4000 \times \mathrm{g}$ for 5 mins) and $4.5 \mathrm{~mL}$ of DTNB $(0.001 \mathrm{M})$ was added to $0.5 \mathrm{~mL}$ of the supernatant. Absorbance was read at $412 \mathrm{~nm}$ against a blank consisting of $0.5 \mathrm{~mL}$ of deproteinizing agent diluted with water $(1: 1, \mathrm{v} / \mathrm{v})$ and $4.5 \mathrm{~mL}$ of DTNB. GSH concentration was extrapolated from calibration curve prepared with GSH standards.

\section{(ix) Estimation of Total Thiol (TSH)}

Total thiol (TSH) content in the kidney homogenate was determined by the method of Ellman (19). The reaction mixture contained 40 $\mathrm{mL}$ of the homogenate, $10 \mathrm{~mL}$ of $10 \mathrm{mM} \mathrm{5,5-}$ dithiobis 2-nitro benzoic acid (DTNB) and $0.1 \mathrm{M}$ potassium phosphate buffer $(\mathrm{pH}$ 7.4) in a final volume of $200 \mathrm{~mL}$. The mixture was incubated for $30 \mathrm{mins}$ at room temperature and the absorbance measured at $412 \mathrm{~nm}$. A standard curve was plotted for each measurement using cysteine as a standard and the results were expressed as $\mathrm{mol} / \mathrm{mg}$ protein.

(x) Estimation of malondialdehyde (MDA) concentration

Total amount of lipid peroxidation products present in the kidney homogenates was estimated by the thiobarbituric acid (TBA) method which measures the malondialdehyde (MDA) reactive products according to the method of Ohkawa (20). A mixture of $0.5 \mathrm{~mL}$ of phosphate buffer $(0.1$ $\mathrm{M}, \mathrm{pH} 8.0), 0.5 \mathrm{~mL}$ of $24 \%$ TCA, $0.5 \mathrm{~mL}$ of the homogenate was incubated at room temperature for $10 \mathrm{mins}$, centrifuged (2000 rpm for $20 \mathrm{mins}$ ). To $1 \mathrm{~mL}$ of supernatant, $0.25 \mathrm{~mL}$ of $0.33 \%$ TBA in $20 \%$ acetic acid was added and boiled at $95^{\circ} \mathrm{C}$ for $1 \mathrm{hr}$. A pink colour product was cooled and absorbance was read at $532 \mathrm{~nm}$.

\section{Statistical Analysis}

All data were expressed as Mean \pm S.D ( $n=5)$. Differences between groups were assessed by analysis of variance (ANOVA) using IBM Statistical Package for Social Sciences (IBM SPSS) software package for Windows (version 13.0).

\section{RESULTS}

Effects of Potassium Bromate $\left(\mathrm{KBrO}_{3}\right)$ and Sodium Nitrite $\left(\mathrm{NaNO}_{2}\right)$ and their combination on Urea, Creatinine and electrolytes

Potassium bromate, sodium nitrite and their combination caused significant $(p<0.05)$ increase in the levels of urea, creatinine and the electrolytes compared to the control [Table 1]. The result also showed that there was an enhanced increase in all these parameters in the combination group as compared with their individual groups.

Effects of Potassium Bromate $\left(\mathrm{KBrO}_{3}\right)$ and Sodium Nitrite $\left(\mathrm{NaNO}_{2}\right)$ and their combination on the levels of NO, MDA, GSH and TSH in the kidney

Potassium bromate, sodium nitrite and 
their combination resulted in significant $(\mathrm{p}<0.05)$ increase in the levels of NO and MDA while there was significant decrease in the levels of the antioxidants GSH and TSH compared to the control [Table 2]. In the combination group, this observation was significantly enhanced in comparison with their individual groups.

Effects of Potassium Bromate $\left(\mathrm{KBrO}_{3}\right)$ and Sodium Nitrite $\left(\mathrm{NaNO}_{2}\right)$ and their combination on the activities of serum arginase and adenosine deaminase (ADA) in the kidney

Individual administration and the combination of potassium bromated and sodium nitrite caused significant $(\mathrm{p}<0.05)$ increase in the activity of arginase and significant decrease in the activity of ADA compared to the control [Table 3]. The combination group resulted in synergistic effects when compared with the individual compound.

Effect of Potassium Bromate $\left(\mathrm{KBrO}_{3}\right)$ and Sodium Nitrite $\left(\mathrm{NaNO}_{2}\right)$ and their combination on antioxidant enzymes: SOD, Catalase and GPx

The oxidative effect of potassium bromate, sodium nitrite and their combination was assessed on the activities of SOD, catalase and GPx [Figure 1,2,3]. Treatment with individual compound caused significant $(\mathrm{p}<0.05)$ suppression in the activities of these antioxidants. Potassium bromate caused significantly higher inhibition in the activities of the enzymes in comparison with sodium nitrite, however, the combination resulted in further inhibition in the activities of these three antioxidants, thereby enhancing the inhibitory activities of the individual compound especially sodium nitrite.

\section{DISCUSSION}

Potassium bromate and sodium nitrite have been extensively used in different processes in the food industry. However, despite their important functions, their toxicity and carcinogenicity induced in various tissues individually have been reported (3). The present work was undertaken to study the combined nephrotoxic effects of $\mathrm{KBrO}_{3}$ and $\mathrm{NaNO}_{2}$ in Wistar rats by measuring different renal function markers. Based on the result, we observed significantly elevated serum levels of creatinine and urea in groups singly administered $\mathrm{KBrO}_{3}$ and $\mathrm{NaNO}_{2}$ as compared to the control. Notably, when these toxicants are administered in combination, they triggered a significant increase in serum level of creatinine and urea compared to groups singly administered $\mathrm{KBrO}_{3}$ and $\mathrm{NaNO}_{2}$ suggesting enhanced kidney dysfunction and renal injuries. As reported by Ogeturk, (9) measurement of serum level of creatinine and urea are essential parameters to assess kidney functions as it reflect changes in the threshold of tubular re-absorption, renal blood flow and glomerular filtration rate (GFR). Elevated serum creatinine and urea levels are associated with decreased GFR caused by chronic renal failure as a result of reduction in the excretion of creatinine by both the glomeruli and the tubules (8). Results from present study therefore confirm earlier findings that potassium bromate and sodium nitrite individually causes severe damage to renal tissues (4) while combination of $\mathrm{KBrO}_{3}$ and $\mathrm{NaNO}_{2}$ enhances renal injury.

Also, we screen for electrolyte/acid-base imbalance in order to monitor the effect of treatment on a known imbalance affecting bodily organ function as suggested by Ijeoma (21). Our result showed significant increase in serum electrolytes $\mathrm{Na}^{+}, \mathrm{Cl}^{-}, \mathrm{HCO}_{3}{ }^{-}$particularly $\mathrm{K}^{+}$was observed to be elevated in groups treated with $\mathrm{KBrO}_{3}$ and $\mathrm{NaNO}_{2}$ singly or in combination. As reported by James (22), potassium is referred as the most credible electrolyte marker of renal failure. This was confirmed as potassium elevation was enhanced in group co-administered $\mathrm{KBrO}_{3}$ and $\mathrm{NaNO}_{2}$ which suggests a complication in the kidney. The increased potassium level could be a result of reduced secretion of potassium in distal tubule during renal failure causing increased potassium in the blood. Of note, a continued increase in potassium level might cause hyperkalemia which is the most significant and life-threatening complication of renal failure (22). Significant increase in $\mathrm{Na}^{+}, \mathrm{Cl}^{-}$ and $\mathrm{HCO}_{3}^{-}$have also been directly linked to nephrotoxicity (21), thereby buttressing the enhanced toxic effect induced by the combination of the two food additives.

In addition to these parameters, arginase activity was screened in kidney homogenates. Arginase is the final enzyme of the urea cycle that converts L-arginine into urea and L-ornithine. Analysis of arginase activity is fundamental to the study of the urea metabolic pathway (23). In the present study, elevated arginase activity in the group that received both $\mathrm{KBrO}_{3}$ and $\mathrm{NaNO}_{2}$ and those administered individual toxicants justifies the high level of urea observed in the study which further suggests renal malfunction and insufficient blood purification. We also assayed for nitric oxide levels. Nitric oxide (NO) is a 
signalling molecule which gives an antiinflammatory effect under normal physiological conditions and also, considered as a proinflammatory mediator that induces inflammation due to over production in abnormal situations causing tissue destruction (24). Excessive production of NO has been implicated in the biosynthesis of potentially harmful reactive nitrogen species (RNS) which is thought to be the prime reason why NO can be considered as proinflammatory mediator (24). In this study, elevated $\mathrm{NO}$ in rats singly administered $\mathrm{KBrO}_{3}$ and $\mathrm{NaNO}_{2}$ signifies tissue damage however, in groups administered both toxicants, enhanced increase in NO level was observed suggesting more damaging effect on renal tissues. This outcome is similar to the report of Gardner (25) which linked high level of nitric oxide (NO) to chronic renal failure.

According to several studies adenosine deaminase (ADA) is one important enzyme that regulates the concentration of available adenosine $(26,27)$. Adenosine is a component of adenine nucleotides including ATP and can be made both from the breakdown of ATP and from degradation of RNA following cell death. Extracellular adenosine acts as modulator in many organs and tissues, but it may act as a physiological regulator as excess can provoke the death of cells (26). The highest concentration of human adenosine deaminase is found in the tissues of the heart, brain, spleen, colon, kidney and lungs (26). In this study, ADA activity in the kidney is significantly decreased in the group of rats administered both $\mathrm{KBrO}_{3}$ and $\mathrm{NaNO}_{2}$ and also in the groups with individual toxicant. This reduction might be a result of impairment of the purine nucleotide metabolism causing defect in the synthesis of adenosine as suggested by Pinheiro (27). The result is also in line with previous reports that stated reductions in ADA activity in renal tissue during toxicity (27).

There is a large body of evidence implicating oxidative stress and reactive oxygen species (ROS) in the mechanism of $\mathrm{KBrO}_{3}$ and $\mathrm{NaNO}_{2}$-induced toxicity in animal models (4). ROS are by-products of aerobic metabolism and excess production cause cellular injury and necrosis via several mechanisms including oxidation of lipids, proteins and DNA (28). Catalase (CAT), super oxide dismutase (SOD) and glutathione peroxidase (GPx) are regarded as first-line defense antioxidants whose roles are indispensable in the defence mechanism of antioxidants (29). Free radicals, especially super oxide anion $\left(\mathrm{O}_{2}\right)$ that is continuously produced in normal body metabolism are suppressed by these antioxidants (29). In this study, the activities of the antioxidant enzymes CAT, SOD, GPx and concentrations of GSH and TSH were found to be significantly lowered in groups treated with $\mathrm{KBrO}_{3}$ and $\mathrm{NaNO}_{2}$ singly and this decrease was enhanced in combination group compared to control group. Lowered activities of these antioxidant enzymes in vivo experimental models have been reported to be connected to overwhelming increase of free radicals (4), which could lead to deleterious effects in the kidney. The results suggest that $\mathrm{KBrO}_{3}$ and $\mathrm{NaNO}_{2}$ administered singly and/or in combination to rats caused severe damage to renal tissues most likely by ROS generation. There are several reasons that could result in the reduced abundance of these molecules: First, there could be loss of these enzyme molecules into the lumen of the tubule due to toxic damage, as suggested for some nephrotoxicants (6). The second possibility is inactivation of these enzymes due to oxidative modification caused by $\mathrm{KBrO}_{3}$ and $\mathrm{NaNO}_{2}(10)$. Moreso, $\mathrm{KBrO}_{3}$ has been reported to act as a strong oxidizing agent (30). Also, malondialdehyde (MDA) known to be the most prevalent by-products of lipid peroxidation (LPO) and has been implicated in the induction of oxidative stress in kidney (5). The level of MDA in renal cells of the rats administered these toxicants singly significantly increased and the increase is further enhanced in the combination group. This supports the significant free radical generation in kidney of treated rats leading to decrease in the antioxidant molecules.

\section{CONCLUSION}

From this present study, it was revealed that the individual nephrotoxic effects of $\mathrm{KBrO}_{3}$ and $\mathrm{NaNO}_{2}$ were enhanced when combined, thereby causing enhanced alteration in the electrolytes panel, depressed antioxidant defense mechanism and possibly causing deleterious alterations in adenosine and arginine metabolism. Therefore, the consumption of food containing these two additives at the tested doses could have enhanced nephrotoxic and oxidative values. Consequently, the use of these toxicants should be in compliance with NADFAC regulation.

Acknowledgments: The authors are thankful to Akanmuli Health Foundation for partial financial support of this project.

Conflicts of Interest: The authors declare no conflict of interest. 


\section{REFERENCES}

1. Abdulmumeen HA, Ahmed NR, Agboola RS. Food its preservatives, additives and applications. International Journal of Chemical and Biochemical Sciences. 2012; 1:36-47.

2. Farombi EO, Alabi MC, Akuru TO. Kolaviron modulates cellular of $\mathrm{CCl}_{4}$ redox status and impairment of membrane protein activities induced by potassium bromate $\left(\mathrm{KBrO}_{3}\right)$ in rats. Pharmaceutical Research. 2002; 45: 63-68.

3. Achukwu PU, Ufelle SA, Ukaejiofo EO, Nwachukwu DN, Nwagha UI, Nworie WC, Anyaehie US. The effect of potassium bromate on some haematological parameters of wistar rats. Nigeria Journal of Physiol Sci. 2009; 24(1): 59-61.

4. Oloyede OB, Sunmonu TO. Potassium bromate content of selected bread samples in Ilorin, Central Nigeria and its effect on some enzymes of rat liver and kidney. Food and Chemical Toxicology, 2009; 47, 2067-2070

5. Dianzani M, Barrera G. Pathology and Physiology of lipid peroxidation and its carbonyl products. In: Alvarez, S.; Evelson, P. (ed.), Free Radical Pathophysiology, 1938 Transworld Research Network: Kerala, India, 2008; 978-817895-311-3.

6. Fatima S, Arivarasu NA, Banday AA, Yusufi AN $\mathrm{K}$, \& Mahmood R. Effect of potassium dichromate on renal brush border membrane enzymes and phosphate transport in rats. Human \& Experimental Toxicology, 2005; 24, 631-638.

7. Sebranek JG, \& Bacus JN. Cured meat products without direct addition of nitrate or nitrite: what are the issues?. Meat science, 2007; 77(1), 136147.

8. Branten AJ, Vervoort G, Wetzels JF. Serum creatinine is a poor marker of GFR in nephrotic syndrome. Nephrology Dialysis Transplant. 2005; 20:707-711.

9. Ogeturk M, Kus I, Colakoglu N, Zararsiz I, Ilhan N, Sarsilmaz M. Caffeic acid phenyl ester protects kidney against carbon tetrachloride toxicity in rats. Journal of Ethnopharmcology, 2005; 97:273-280.

10. Ahmad MK, Ashreeb N, Mohd F, Riaz M. Oral administration of a nephrotoxic dose of potassium bromate, a food additive, alters renal redox and metabolic status and inhibits brush border membrane enzymes in rats. Food Chemistry; 2012; 134: 980-985.

11. Oyenihi OR, Afolabi BA, Oyenihi AB, Ogunmokun OJ, Oguntibeju OO.. Hepato-and neuro-protective effects of watermelon juice on acute ethanol-induced oxidative stress in rats. Toxicology reports, 2016; 3, 288-294.

12. Miranda KM, Espay MG, \& Wink DA. A rapid, simple spectrophotometric method for simultaneous detection of nitrate and nitrite. Nitric Oxide, 2001; 5, 62-71.

13. Romero MJ, Platt DH, Tawfik HE, Labazi M, ElRemessy AB, Bartoli M et al. Diabetes-induced coronary vascular dysfunction involves increased arginase activity. Circ Res 2008; 102:95-102.

14. Giusti G, Galanti B. Colorimetric method. In: HU Bergmeyer, ed. Methods of Enzymatic Analysis. Weinheim: Verlag Chemie: 1984; 315323.

15. Aebi H. Catalase in vitro. Methods in Enzymology 1984; 105: 121-126.

16. McCord JM, and Fridovich I. Superoxide dismutase, an enzymatic function for erythrocuperin (hemocuperin). The journal of Biological Chemistry 1969; 244: 6049-6053.

17. Rotruck TT, Ganther HE, Swanson AB, Hafeman DG, and Hoeckstra WG. Selenium: Biochemical role as a component of glutathione peroxidase. Science. 1973; 179: 588-590.

18. Jollow DJ, Mitchell JR, Zampaglione N, Gillete JR. Bromobenzene induced liver necrosis. Protective role of glutathione and evidence for 3 , 4-bromobenzene oxide as a hepatotoxic metabolite. Pharmacology, 1974; 11:151-169.

19. Ellman GL. Tissue sulfhydryl groups. Arch. Biochem. Biophys., 1959; 82:70-77.

20. Ohkawa H, Ohishi N, and Yagi K. Assay for lipid peroxides in animal tissues by thiobabituric acid reaction. Analytical Biochemistry, 1979; 95:351358.

21. Ijeomah AU, Ugwu MN, and Dasofunjo K. Long term effect of artemisinin combination therapies (acts) on the kidney function and electrolyte balance in healthy male Wistar rats. CIBTech Journal of Pharmaceutical Sciences, 2018; 7(2), $1-8$.

22. James S, Mitchel G. Physiology and disorder of water electrolytes and acid base metabolism. In: Carl AB, Edward R, David E, editors. Tietz Textbook of clinical chemistry and molecular diagnostics. $4^{\text {th }}$ ed. New Delhi: Elsevier Inc; 2006; pp. 1747-1776.

23. Parikh CR, Koyner JL, Chertow GM, Marsden PA, Taal MW. and YuA SL. Biomarkers in Acute and Chronic Kidney Diseases. $10^{\text {th }}$ edition. Philadelphia 2016.

24. Sharma JN, Al-Omran A, Parvathy SS. Review Role of nitric oxide in inflammatory diseases. Inflammopharmacology 2007; 15: 252-259.

25. Gardner AM, and Gardner PR. Flavohemoglobin detoxifies nitric oxide in aerobic but not anaerobic Escherichia coli. Evidence for a novel inducible anaerobic nitric oxide scavenging activity. 2002;277.8166.8171.

26. Jacobson KA, Hoffmann C, Cattabeni F, Abbracchio MP. Adenosineinduced cell death: evidence for receptor-mediated signalling. Apoptosis; 1999; 4: 197-211.

27. Pinheiro FV, Pimentel VC, De Bona KS, Scola G, Salvador M, Funchal C and Moretto MB. Decrease of adenosine deaminase activity and increase of the lipid peroxidation after acute methotrexate treatment in young rats: protective effects of grape seed extract. Cell Biochemistry 
and function; 2010; 28: 89-94.

28. Karbownik M, Stasiak M, Zygmunt A, Zasada K, and Lewinski A. Protective effects of melatonin and indole-3-propionic acid against lipid peroxidation, caused by potassium bromate in the rat kidney. Cell Biochemistry and Function, 2006; 24, 483-489.

29. Ighodaro OM, and Akinloye OA. First line defence antioxidants-superoxide dismutase
(SOD), catalase (CAT) and glutathione peroxidase (GPX): Their fundamental role in the entire antioxidant defence grid. Alexandria Journal of Medicine, 2018; 54(4), 287-293.

30. Kurokawa Y, Maekawa A. and Takahashi M. Toxicity and Carcinogenicity of potassium bromate - a new renal carcinogen. Environmental Health perspective. 1990; 87: 309 -335 . 
Table 1 - Effect of Potassium Bromate $\left(\mathrm{KBrO}_{3}\right)$ and Sodium Nitrite $\left(\mathrm{NaNO}_{2}\right)$ and their combination on Urea, Creatinine and electrolytes

\begin{tabular}{|c|c|c|c|c|c|c|}
\hline Treatment & $\begin{array}{l}\text { Urea } \\
(\mathrm{mmol} / \mathrm{L})\end{array}$ & $\begin{array}{l}\text { Creatinine } \\
(\mathrm{mmol} / \mathrm{L})\end{array}$ & $\begin{array}{l}\mathrm{HCO}_{3}^{-} \\
(\mathrm{mmol} / \mathrm{L})\end{array}$ & $\begin{array}{l}\mathrm{Cl}^{-} \\
(\mathrm{mmol} / \mathrm{L})\end{array}$ & $\begin{array}{l}\mathrm{Na}^{+} \\
(\mathrm{mmol} / \mathrm{L})\end{array}$ & $\begin{array}{l}\mathrm{K}^{+} \\
(\mathbf{m m o l} / \mathbf{L})\end{array}$ \\
\hline Control & $\begin{array}{l}8.3 \pm 1.30 \\
(5.07-11.53)\end{array}$ & $\begin{array}{l}96.67 \pm 25.170 \\
(34.15-159.18)\end{array}$ & $\begin{array}{l}24 \pm 1.00 \\
(21.52-26.48)\end{array}$ & $\begin{array}{l}110 \pm 3.00 \\
(102.55-117.45)\end{array}$ & $\begin{array}{l}150 \pm 5.00 \\
(137.58-162.42)\end{array}$ & $\begin{array}{l}7 \pm 0.87 \\
(4.85-9.15)\end{array}$ \\
\hline $\begin{array}{l}\text { PBR } \\
(20 \mathrm{mg} / \mathrm{kgbw})\end{array}$ & $\begin{array}{l}13.23 \pm 0.93^{\mathrm{a}, \mathrm{d}} \\
(10.93-15.54)\end{array}$ & $\begin{array}{l}150 \pm 13.23^{\mathrm{a}, \mathrm{c}, \mathrm{d}} \\
(117.14-182.86)\end{array}$ & $\begin{array}{l}45.33 \pm 4.16^{\mathrm{a}, \mathrm{c}, \mathrm{d}} \\
(34.99-55.68)\end{array}$ & $\begin{array}{l}152 \pm 6.56^{\mathrm{a}, \mathrm{c}} \\
(135.71-168.29)\end{array}$ & $\begin{array}{l}160 \pm 8.66^{\mathrm{a}, \mathrm{c}, \mathrm{d}} \\
(138.49-181.51)\end{array}$ & $\begin{array}{l}28.67 \pm 5.58^{\mathrm{a}, \mathrm{c}, \mathrm{d}} \\
(14.82-42.52)\end{array}$ \\
\hline $\begin{array}{l}\text { SNT } \\
(60 \mathrm{mg} / \mathrm{kgbw})\end{array}$ & $\begin{array}{l}13.03 \pm 2.45^{\mathrm{a}, \mathrm{b}, \mathrm{d}} \\
(6.94-19.13)\end{array}$ & $\begin{array}{l}145 \pm 5^{\mathrm{a}, \mathrm{b}, \mathrm{d}} \\
(132.58-157.42)\end{array}$ & $\begin{array}{l}42.33 \pm 2.08^{\mathrm{a}, \mathrm{d}} \\
(37.16-47.50)\end{array}$ & $\begin{array}{l}147 \pm 3.61^{\mathrm{a}} \\
(138.04-155.96)\end{array}$ & $\begin{array}{l}163.33 \pm 2.89^{\mathrm{a}, \mathrm{d}} \\
(156.16-170.50)\end{array}$ & $\begin{array}{l}27 \pm 5.22^{\mathrm{a}, \mathrm{b}, \mathrm{d}} \\
(14.03-39.97)\end{array}$ \\
\hline $\begin{array}{l}\mathrm{PBR}+\mathrm{SNT} \\
(20 \mathrm{mg} / \mathrm{kgbw}+ \\
60 \mathrm{mg} / \mathrm{kgbw})\end{array}$ & $\begin{array}{l}17.8 \pm 0.87^{\mathrm{a}, \mathrm{b}, \mathrm{c}} \\
(15.63-19.97)\end{array}$ & $\begin{array}{l}166.67 \pm 5.77^{\mathrm{a}, \mathrm{b}, \mathrm{c}} \\
(152.32-181.01)\end{array}$ & $\begin{array}{l}50.33 \pm 2.52^{\mathrm{a}, \mathrm{c}} \\
(44.08-56.58)\end{array}$ & $\begin{array}{l}172.67 \pm 19.40^{\mathrm{a}, \mathrm{b}, \mathrm{c}} \\
(124.48-220.86)\end{array}$ & $\begin{array}{l}186.67 \pm 2.89^{\mathrm{a}, \mathrm{b}, \mathrm{c}} \\
(179.50-193.84)\end{array}$ & $\begin{array}{l}55.43 \pm 2.00^{\mathrm{a}, \mathrm{b}, \mathrm{c}} \\
(50.46-60.41)\end{array}$ \\
\hline
\end{tabular}

Results represent Mean \pm S.D ( $(n=5) .{ }^{a}$ significantly different from control, ${ }^{b}$ significantly different from $\mathrm{KBrO}_{3}$

${ }^{\mathrm{c}}$ significantly different from $\mathrm{NaNO}_{2},{ }^{\mathrm{d}}$ significantly different from $\mathrm{KBrO}_{3}+\mathrm{NaNO}_{2}$

Significance difference $=95 \%$ Confidence interval $(\mathrm{CI})$

Table 2 - Effect of Potassium Bromate $\left(\mathrm{KBrO}_{3}\right)$ and Sodium Nitrite $\left(\mathrm{NaNO}_{2}\right)$ and their combination on the levels of NO, MDA, GSH and TSH in the kidney

\begin{tabular}{lllll}
\hline Treatment & $\begin{array}{l}\text { NO } \\
\text { nmol/mg protein }\end{array}$ & $\begin{array}{l}\text { MDA } \\
\mu \text { mol of MDA/mg protein }\end{array}$ & $\begin{array}{l}\text { GSH }(\mu \mathrm{mol} / \mathrm{mg} \\
\text { protein })\end{array}$ & $\begin{array}{l}\text { TSH } \\
(\mu \mathrm{mol} / \mathrm{mg} \text { protein })\end{array}$ \\
\hline Control & $\begin{array}{l}84.70 \pm 4.19 \\
(74.30-95.10)\end{array}$ & $\begin{array}{l}2.15 \times 10^{-6} \pm 1.23 \times 10^{-6} \\
\left(-9.09 \times 10^{-7}-5.22 \times 10^{-6}\right)\end{array}$ & $\begin{array}{l}10.29 \pm 0.24 \\
(9.70-10.88)\end{array}$ & $\begin{array}{l}4.20 \pm 0.06 \\
(4.04-4.36)\end{array}$ \\
& & & & \\
PBR (20mg/kgbw) & $117.82 \pm 1.50^{\mathrm{a}, \mathrm{d}}$ & $7.27 \times 10^{-6} \pm 1.01 \times 10^{-6 \mathrm{a}, \mathrm{d}}$ & $3.27 \pm 0.14^{\mathrm{a}, \mathrm{d}}$ & $0.55 \pm 0.08^{\mathrm{a}, \mathrm{c}, \mathrm{d}}$ \\
& $(114.09-121.56)$ & $\left(4.75 \times 10^{-6}-9.78 \times 10^{-6}\right)$ & $(2.91-3.63)$ & $(0.34-0.75)$ \\
& & & & \\
SNT (60mg/kgbw) & $117.09 \pm 0.72^{\mathrm{a}, \mathrm{d}}$ & $6.95 \times 10^{-6} \pm 2.12 \times 10^{-7 \mathrm{a}, \mathrm{b}, \mathrm{d}}$ & $3.23 \pm 0.00^{\mathrm{a}, \mathrm{d}}$ & $0.72 \pm 0.08^{\mathrm{a}, \mathrm{b}, \mathrm{d}}$ \\
& $(115.30-118.88)$ & $\left(6.55 \times 10^{-6}-7.31 \times 10^{-6}\right)$ & $(3.22-3.24)$ & $(0.52-0.93)$ \\
PBR+SNT (20mg/kgbw + & $139.65 \pm 3.59^{\mathrm{a}, \mathrm{b}, \mathrm{c}}$ & $9.29 \times 10^{-6} \pm 3.35 \times 10^{-7 \mathrm{a}, \mathrm{b}, \mathrm{c}}$ & $2.82 \pm 0.06^{\mathrm{a}, \mathrm{b}, \mathrm{c}}$ & $0.25 \pm 0.06^{\mathrm{a}, \mathrm{b}, \mathrm{c}}$ \\
60mg/kgbw) & $(130.73-148.57)$ & $\left(8.45 \times 10^{-6}-1.01 \times 10^{-5}\right)$ & $(2.66-2.98)$ & $(0.09-0.40)$ \\
& & & & \\
\hline
\end{tabular}

Results represent Mean \pm S.D ( $\mathrm{n}=5$ ). ${ }^{\mathrm{a}}$ significantly different from control, ${ }^{\mathrm{b}}$ significantly different from $\mathrm{KBrO}_{3}$ ${ }^{\mathrm{c}}$ significantly different from $\mathrm{NaNO}_{2},{ }^{\mathrm{d}}$ significantly different from $\mathrm{KBrO}_{3}+\mathrm{NaNO}_{2}$,

Significance difference $=95 \%$ Confidence interval $(\mathrm{CI})$ 
Table 3 - Effect of Potassium Bromate $\left(\mathrm{KBrO}_{3}\right)$ and Sodium Nitrite $\left(\mathrm{NaNO}_{2}\right)$ and their combination on the activities of serum arginase and adenosine deaminase (ADA) in the kidney

\begin{tabular}{lll}
\hline Treatment & $\begin{array}{l}\text { Arginase }(\mathrm{nmol} / \mathrm{min} / \mathrm{mg} \\
\text { protein) } / /\end{array}$ & ADA (units/L) \\
\hline Control & $27.02 \pm 2.35$ & $7.52 \pm 0.35$ \\
& $(21.19-32.85)$ & $(6.66-8.38)$ \\
PBR (20mg/kgbw) & $62.27 \pm 2.16^{\mathrm{a}, \mathrm{c}, \mathrm{d}}$ & $1.35 \pm 0.37^{\mathrm{a}, \mathrm{cd}}$ \\
& $(56.90-67.64)$ & $(0.44-2.26)$ \\
SNT (60mg/kgbw) & $62.84 \pm 5.74^{\mathrm{a}, \mathrm{d}}$ & $2.79 \pm 0.12^{\mathrm{a}, \mathrm{b}, \mathrm{d}}$ \\
& $(48.59-77.09)$ & $(2.50-3.07)$ \\
PBR+SNT $(20 \mathrm{mg} / \mathrm{kgbw}+60 \mathrm{mg} / \mathrm{kgbw})$ & $91.98 \pm 3.52^{\mathrm{a}, \mathrm{b}, \mathrm{c}}$ & $0.61 \pm 0.34^{\mathrm{a}, \mathrm{b}, \mathrm{c}}$ \\
& $(83.23-100.72)$ & $(-0.23-1.45)$ \\
\hline
\end{tabular}

Results represent Mean \pm S.D ( $n=5),{ }^{a}$ significantly different from control, ${ }^{b}$ significantly different from $\mathrm{KBrO}_{3}$ ${ }^{\mathrm{c}}$ significantly different from $\mathrm{NaNO}_{2},{ }^{\mathrm{d}}$ significantly different from $\mathrm{KBrO}_{3}+\mathrm{NaNO}_{2}$

Significance difference $=95 \%$ Confidence interval $(\mathrm{CI})$

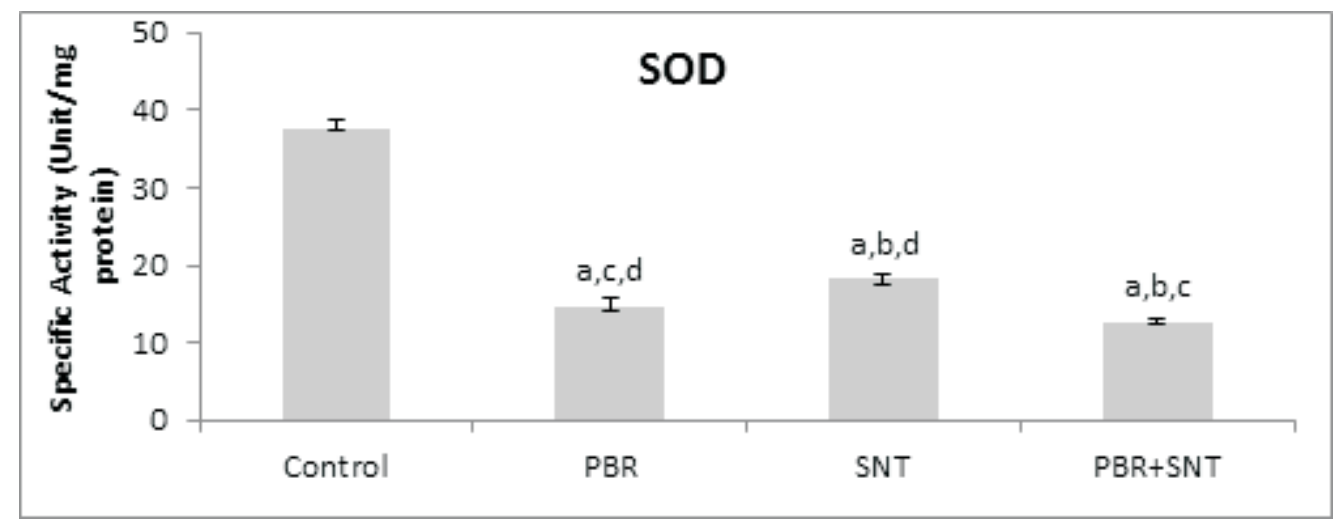

Figure 1a - Effect of Potassium Bromate $\left(\mathrm{KBrO}_{3}\right)$ and Sodium Nitrite $\left(\mathrm{NaNO}_{2}\right)$ and their combination on the activities of super oxide dismutase (SOD) in kidney homogenates.

Orientation: Portrait

Results are Mean $\pm \operatorname{SD}(n=5)$.

a,b,c,d significantly different from control, $\mathrm{KBrO}_{3}, \mathrm{NaNO}_{2}$ and $\mathrm{KBrO}_{3}+\mathrm{NaNO}_{2}$ respectively

Significance difference $=95 \%$ Confidence interval $(\mathrm{CI})$ 


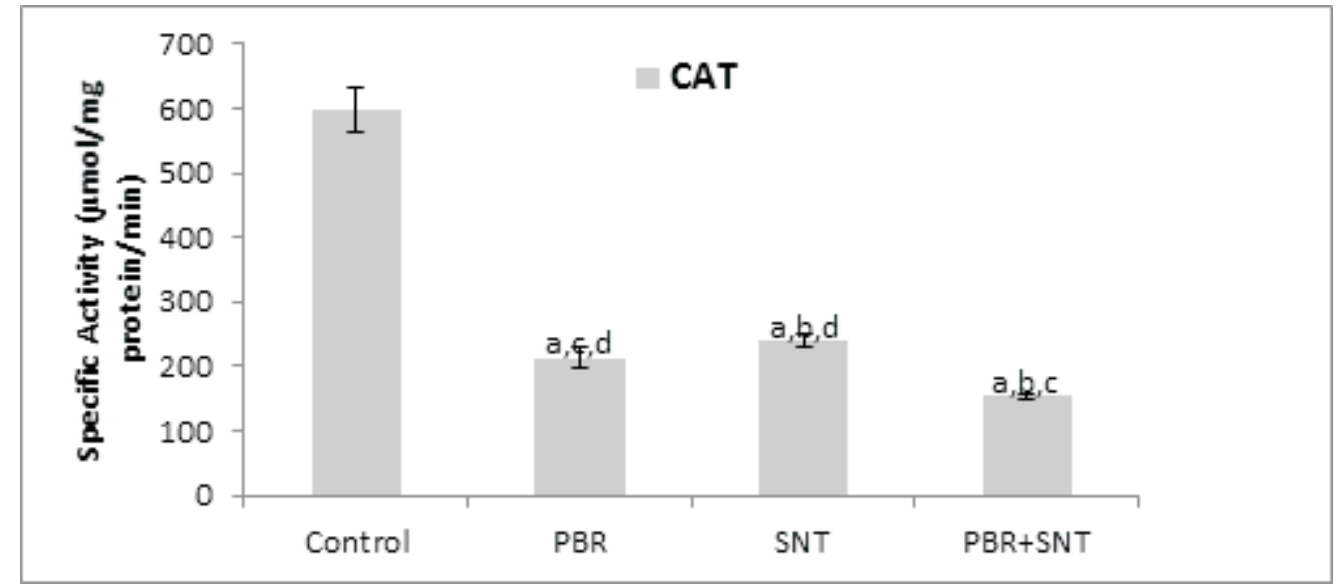

Figure 1b - Effect of Potassium Bromate $\left(\mathrm{KBrO}_{3}\right)$ and Sodium Nitrite $\left(\mathrm{NaNO}_{2}\right)$ and their combination on the activities of catalase (CAT) in kidney homogenates.

Orientation: Portrait

Results are Mean $\pm \operatorname{SD}(n=5)$.

a,b,c,d significantly different from control, $\mathrm{KBrO}_{3}, \mathrm{NaNO}_{2}$ and $\mathrm{KBrO}_{3}+\mathrm{NaNO}_{2}$ respectively

Significance difference $=95 \%$ Confidence interval $(\mathrm{CI})$

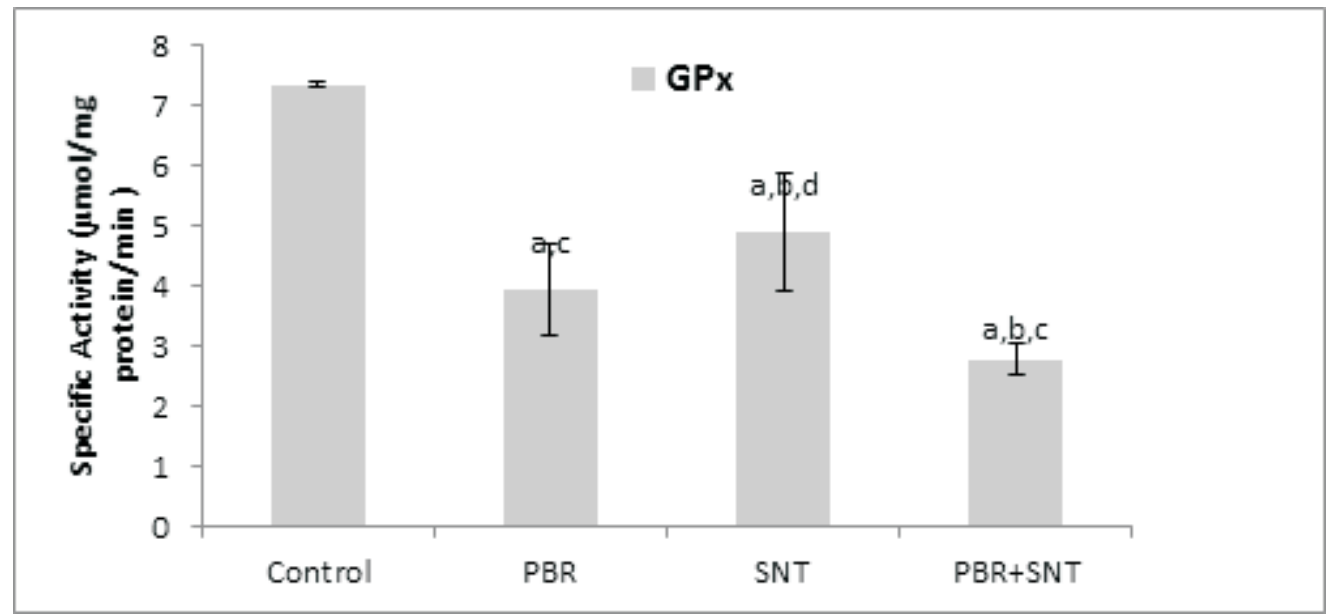

Figure 1c - Effect of Potassium Bromate $\left(\mathrm{KBrO}_{3}\right)$ and Sodium Nitrite $\left(\mathrm{NaNO}_{2}\right)$ and their combination on the activities of glutathione peroxidase (GPx) in kidney homogenates.

Orientation: Portrait

Results are Mean $\pm \operatorname{SD}(n=5)$.

a,b,c,d significantly different from control, $\mathrm{KBrO}_{3}, \mathrm{NaNO}_{2}$ and $\mathrm{KBrO}_{3}+\mathrm{NaNO}_{2}$ respectively

Significance difference $=95 \%$ Confidence interval $(\mathrm{CI})$ 